\title{
A Private Central Bank: Some Olde English Lessons
}

\author{
G. J. Santoni
}

ISSATISFACTION with persistent and volatile inflation since the mid-1960s has led to numerous calls for a different approach to monetary policy. In some cases, people have suggested that monetary policy decisions be made more explicitly political, for example, subject to greater control by Congress via congressionally mandated monetary growth targets. In the same vein, Milton Friedman has proposed that monetary policy be set by the Treasury, thus making the President of the United States ultimately responsible for its conduct.

In contrast, some critics of the current system have argued for a return to the constraints of Bretton Woods or the even earlier classical gold standard. Some have suggested that the only lasting solution to the problem entails the private production of money.

Behind these different suggestions is the implication that central bankers will respond systematically and, hence, predictably to the different incentives embodied in these alternative programs of monetary control. If the incentives are changed, so the theory goes, better policy decisions will be made.

This paper focuses directly on the theoretical and empirical support for the daim that different incen tives induce policymakers to choose different monetary growth rates. This paper does not advocate a particular set of incentives or form of organization for the central bank. Rather, it merely points out that the choices of monetary policymakers depend, as all choices do, upon the set of incentives the individual confronts.

G. J. Santoni is a senior economist at the Federal Reserve Bank of St. Louis. Thomas A. Pollmann provided research assistance.
A verification of this proposition is sought by examining the behavior of the Bank of England over the period from, roughly, 1700 to 1930 . This period, which encompasses two significant changes in the incentives facing England's central bankers, provides support for the view that policymakers, like other individuals, respond predictably to changes in the cost-reward circumstances facing them.

\section{WIAT DISTINGUTSHES CENTRAL BANKETS?}

The central banker is the person (or group/ holding the enforceable right to control the quantity of nominal money balances in circulation. ${ }^{1}$ This right is valuable. Whoever holds it can, among other things, materially influence the rate of inflation and the flow of profits from money creation iseigniorage, as well as the present value of the right itself.

\section{WHY THE BANK OF ENGLAND?}

The Bank of England presents an interesting case in studying the effect of different incentives on the behavior of central bankers. There are two reasons for this. First, the original organization of the Bank differed from its modern counterparts in one fundamental respect: the Bank of England was a privately-owned-forprofit central bank from its inception in 1694 until the

\footnotetext{
"More precisely, they control the issuance of "high-powered money" or base money. Since the long-run link between base money and the transaction batances of the public (money) is so close, the paper treats the right to control base money as synonymous with the right to control money. See Balbach (7981); Johannes and Rasche (1979).
} 
early 1930 s. Further, the Bank was immersed in a set of institutional arrangements that related the wealth of the Bank's owners inversely to the rate of inflation. This paper shows that the costs and benefits of varying monetary growth rates were different for England's private for-profit central bankers than those typically taken into account by modern central bankers. ${ }^{2}$ Consequently, a different monetary growth rate emerged.

A second reason for studying this particular case is that control of the money supply by the Bank's owners was interrupted from 1793 to 1821 , when the government seized the Bank's monetary control function. For the purposes of this paper, the interfuption is important because it allows a contrast of monetary growth outcomes produced by certain identifiable changes in the incentive structure, while other important institutional factors remained roughly constant.

\section{A BRIEF HISTORY OF THE BANK OF ENGLAND: 1694-1832}

Prior to 1694, England's money supply consisted mainly of coins. These coins were controlled by the government through regulation of the mint.

The coins were in a continually bad state because the populace persisted in clipping, sweating, filing, washing and boring them. Further, the government resolted to progressive debasement in the form of fre quent recoinages, a practice that was particularly pronounced during the reigns of Henry VIII and Edward VI. ${ }^{3}$

In some cases, the government expropriated monetary wealth outright. In 1640 , Charkes I closed the London Mint and confiscated the funds of private citizens that had been stored there for safekeeping. Later, in 1672 , Charles II expropriated funds deposited with the Treasury by London goldsmiths. ${ }^{+}$This irresponsible behavior had important consequences when, in 1692 and 1693 , William III floated long-term loans to finance a war with France. Because of the earlier debasements

\footnotetext{
${ }^{2}$ Alchian (1977), pp. $127-50$.

${ }^{3}$ Kemmerer (1944), pp, 34-36

${ }^{4}$ Charles finally acknowledged one-half the debt, but the promise to pay was never kept. Payments, at the rate of 6 percent, were made only during the period $1677 \mathrm{~m} 83$. Charles explained the reason for his action as lollows:

Whereas since the time of our happy Restoration We have been involved in great Forreigne Warrs as well tor the Safely of our Government as the vindication of the Rights and Privileges of our Subjects, in the prosecu tion whereof we have been constreyned for some years past, contrary to our Inctinacions, to postpone the payment of the moneys due from Us to
}

and expropriations, the interest rates demanded for long-term loans to the Crown contained a substantial premium.5

\section{Establishment of the Bank}

William's war with France was a costly affair. When additional funds were required in 1694 , a proposal that twice previously had been put forward by William Paterson was adopted in the Ways and Means Act of that year. 'The Act provided that those who subscribed

for and towards the raising and paying into the receipt of the Exchequer the said sum of twelve hundred thousand pounds part of the sum of fifteen hundred thousand pounds were to constitute jointly the Company of the Bank of England. ${ }^{\text {. }}$

The loan was a perpetuity, paying interest at the rate of 8 percent. This was considerably below the interest rates that previously had been charged the Crown. The subscibers, however, received additional rights to 1 ! form a joint stock banking company, 2) deal in bills of exchange, gold and silver, 3 grant advances on security, and 4) issue promissory notes transfexable by endorsement in an amount not exceeding the Bank's capital. ${ }^{7}$

These terms apparently were very attractive. The entire loan was subscribed within 12 days. Every sub-

several Goldsmiths and other upon Talys struck . . . And although the present Posture of Our affaires cannot reasonably spare so greate a sum as must be applied to the satistaction of those debts, Yet considering the great difficulty which very many of our Loving Subjects (who putt their moneys into the hands of those Goldsmiths and others from whom we received it) doe at present Lye under, almost to their utter ruine for want of their said moneys. We have rather chose out of our princely care and compassion towards Our people, to suffer in Our owne Affaires than that our toving subjects should want soe reasonable a Peliete.

Bisschop (1967), p. 48. Incidentally, tallys were pieces of wood upon which government indebtedness was recorded. The govern. ment issued tallys when it borrowed from individuals. Goldsmiths regularly accepted these tallys and credited the accounts of the depositors

${ }^{5}$ Homer (1977), p. 126. Both loans were of 1 million pounds. The first was a life annuity paying interest of 10 percent until 1700 and 7 percent thereafter on a semitontine basis (surviving subscribers spit one-half the proceeds due decedent subscribers). The second loan paid interest at the rate of 14 percent

${ }^{6}$ Bisschop, p. 74, and Clapham (1958), vol. 1, pp. 16-20.

${ }^{7}$ Bisschop, pp. 70-71, and Macleod (1897), pp. 773 and 776 . The Bank employed three methods of accounting for the transaction accounts ("running cash") of its depositors and these methods define how the balances were transferred in the exchange process. The methods were by "Notes payable to Bearer, to be endorsed," by "Books or Sheets of Paper, wherein their Account to be entered, "or by "Notes to persons to be accomptable." The first method was the torerunner of central bank notes. The third was essentialy equivalent to a present-day checking account. The second was much like modern passbook accounts. See Clapham, vol. 1, p. 21. 
scriber became a shareholder of the Bank to the extent of his subscription, and all or any fraction of his share could be sold to others."

The Bank opened for business on July 27,1694 , in Mercers' Chappell. From its inception, every effort was made by the Governor and Court of Directors 1 Board of Directors of the Bank to attract depositors and to promote the circulation of its "running cash notes.": These notes were comertible in to legal tender money, gold coins, at a fixed exchange rate upon demand at the Bank."

Subsequent legislation strengthened the Bank's position. The Bank was granted a monopoly in joint stock banking in early $1697^{1:}$ In 1708 , the Bank obtained a monopoly in the issue of joint stock bank notes. ${ }^{12}$ Later, in 1742 , Act 10 and 11 George II., C. 13 par. 5], neaffimed the ealied rights granted to the Bank. Each of these pieces of legislation was accompanied by an additional Bank loan to the govemment. The Bank subseribed an additional $1,001,017$ pounds for loan to the government at 8.0 pereent in 1697 . In 1707 , in extended a $1,500,000$ pound lom at 4.5 percent to the govermont and in 1742 , another $1,600,000$ pounds at 3.0 pereont.

No furher signficant legishative changes roguding the Bank's posibion oceured until 1826 . In that veat, the Bank's nonopoly on joint stock banking was limiled to whin a 65 -mile radius of London. "Seven vears later, in 1833. its monopoly of point shock bank note

\footnotetext{
${ }^{8}$ Bank shares exchanged hands regularly and, in 1747 , Gentemar's Magazine began publishing daily price quotes for Bank of England shares of stock. in 1773 New Jonathan's Coffee House printed the words, "The Stock Exchange" over its door and admittance was permitied only by fee.

${ }^{3}$ Clapham, vol. 1. pp. $20-23$.

${ }^{10}$ It is interesting to note that an official (established by law) gotd standard was not entorced in England at this time. The Banks commitment to redeem its notes at a fixed price in tems of gold was not foisted upon the Bank by the government. Rather, this was a voluntary contract established by the Bank with its customers. England's official gold standard was not astablished until 1821 (more than 100 years latef) and then only as a result of the Bank's insistence

"Clapham, vol. 1 : pp. 46-50

${ }^{2}$ Bisschop, pp. 82-83. Act 7 Anne, C. 7 , provides that during the continuance of the said corporation of the Governor and Company of the Bank of England, it shall no be law ful for any body politic or corporate whatsoever, created or to be created (other than said Governor and Company of the Bank of England, or for any other persons whatsoever, united or to be united in covenants, or part nership, exceeding the number of six persons, in that part of Great Britain called England, to borrow. owe, or take up any sum or surns of money on their bils of notes payable at demand or at a less time ther six months from botrowing thereof."
}

issue was also limited to the same area. However, Bank of England notes were made legal tender at this time. ${ }^{3+}$ This legislation provided legal force to the practice that had already been adopted by other banks of maintaining their reserves in the form of Bank of England notes.

\section{The Government Steps In: 1793-1821}

The Napoleonic Wars between England and Fance began in 1793. With the exception of a minos truce, the war continued until Napoleon's abdication on April 6 , 1814. Govermment demands from the Bank for financm ing rose substantially during the war. Of course, the Bank's contract with its depositors to redeem its notes at a fixed price in terms of gold got in the way of the government's interest and, on february 26,1797 , the King and Privy Council ordered the Bank to suspend specie payments, a suspension that was to last for more than 20 years. ${ }^{16}$

Duning the suspension, control of the money supply, which had rested with the Bank's owners, was lavgely usumed by the govemment. Clapham notes that

The minutes of the cout and those of the Commitue of Theasury are full of ..... requests for help from pereval and of the Banks reluctant bul invariable a guescence.

The Bank apparontly acquesced because of an "understanding a gentlenan's undertanding . . lo do this business and to do in in the way mos comenient to the "Trasury"

Given the ranser of monetary controt the sovernment, if is, pertaps, not supprising that the Bank's boand of birechors becme unusually lackatatical in their attention to duties. As a result of absenteoism, the Bank Cour experienced dificuly in maintaning a quorum. Letler's were sent to a number of directors that "pointedly asked "when their attendance could be cepended upon" for" "too much of the business had

\footnotetext{
${ }^{13}$ Bisschop, p. 198.

${ }^{14}$ Andreades (1924), p. 261; Bisschop. p. 198

${ }^{15}$ There was, of course, Napoleon's "Campaign of 100 Days" be Iween his escape from Eloa on March 1, 1815, and his deleat at Waterioo on June 18, 1815. Due to its brevity: it is ignored in this analysis.

${ }^{16}$ The wording of the order ran as follows: The Bank will "rorbear issung any Cash in Payment until the Sense of Parlament can be taken on that Subject." Clapham, vol. 1, 0.272

${ }^{17}$ Clapham, vol. 2 , p. 33; see, as well, Viner (1937), p. 122; Cannan (1919). p $x$

${ }^{18}$ Clapham, vol. 2, p. 11

${ }^{19}$ Clapham, vol. 2, p. 31
} 
been done by a Single Director with the assistance of the Head of the Discount Office'."'s

\section{Return tor Private Control}

The suspension played an important role in the govermment's effort to west control of the money supply from the Bank, In the absence of suspension, "control" of the stock of noney would have meant little to the govemment since the requirement to redem notes at a fixed price in terms of specie eventually would have and did during 1790-96 placed an effective constraint on note issue.

The public was never keen on the suspension, and the Bank made this the political issue in its fight to regain control of the money supply. In October of 1797 , six months after it was ordered to suspend payments. the Bank indicated that it could "with safety resume its accustomed functions (payment of specie), if the political circumstances of the country do not render it inexpedient." "20 The Bank's report was virtually ignored by government. In June of 1810 , the "Report from the Select Committee on the High Price of Bullion" recommended to Parliament that the resumption of specie payments at the old par begin within two years. The issue was not even taken up for discussion unt July of the following year. ${ }^{2}$ A vote on the recommendation was taken in the House of Commons in 1811. The Iouse voted 180 to 45 against the issue.

On its own initiative, the Bank began partial resumption of specie payments for notes of 5 pounds or less in January of 1817. Early in 1819, however, Parlament required the Bank to discontinue the practice. ${ }^{22}$ Parliament had promised on five different occasions to eventually retum to specie payments, but continued to drag its feet on fixing a date. Finaly, on July 2,1819 , the House of Commons passed an act pemitting the resumption of cash payments (nullion and coint after May 1, 1822. At the request of the Bank, this date eventually was moved forward to May $1,1821$.

\section{SOME TMPOTTANT OBSERVATIONS}

There are a number of important points to draw from the previous discussion in andveing the incen-

\footnotetext{
${ }^{20}$ Clapham, vol. 1, p. 272 . See, as well, Cannan, p. xi.

2:Viner, p. 171

22 Viner, p. 172

${ }^{23}$ Viner, pp. $172-73$
}

tives faced by the central bankers. First, given the one exception noted, the right to control the money supply was held privately. This right in the form of ownership shares in the Bank, was traded in an organized market Any expected changes in the future profits of the Bank would be reflected by changes in the price of Bank shares and would immediately affect the weath of Bank owners.

Second, the owners of the Bank had loaned considerable sums to the government in perpetuity at fixed rates of interest. By 1743 , the sum was well in excess of nine million pounds.

Finaly, the Bank's contract with its customers to redeem its notes at a fixed price in terms of gold was a voluntary arangement. An official testablished by law? gold standard did not exist in England until 1821. In fact, the gold standard came about largely as a result of the Bank's continuous prods to an unwiling Pardia ment.

The following discusses how this unique incentive structure faced by England's central bankers infuenced the monetary growth rate.

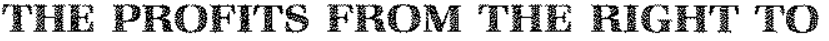 CONTTOL MONEY}

Like the right to control the production of any commodity, the right to controt the production of money is valuable. The central bank, at the cost of a few cents worth of paper and ink, can produce a $\$ 100$ bill tor a 100-pound notel that can be exchanged in the market for $\$ 100$ worth of resources.

\section{The Flow of Profits}

The central bank introduces money into cincuation by exchanging units of money which it prints for commodities. These commodities may be either real or financial assets. Since the bank buys these assets at market prices, the expected flow of nominal profits generated by the purchase of the assets is equal to the nominal interest rate times the price of the assets purchased. This is equivalen to the nominal interesl rate multiplied by the quantity of money exchanged for the assets. The flow of real revenue is smply the nominal flow divided by the price level is $\times \mathrm{M}$ P.

Since we are interested in relating the bank's real revente thow to the rate of money production, account must be taken of the fact that, at higher rates of money production thigher mates of inflation, people will want 


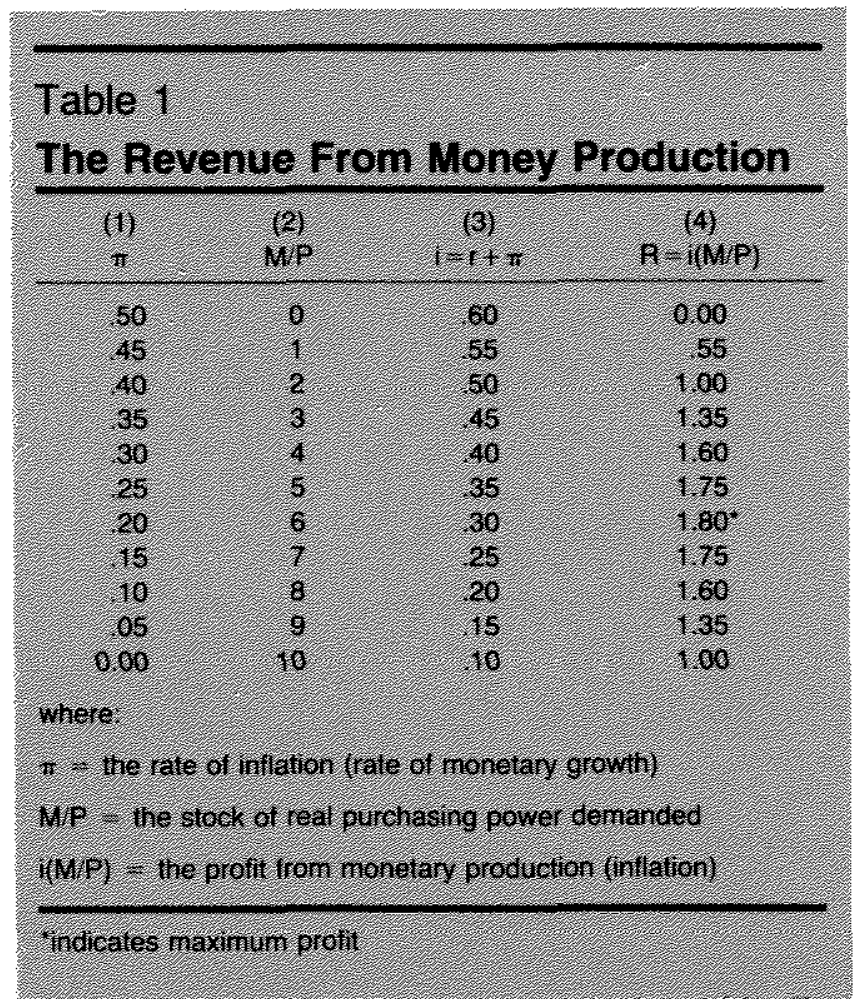

to hold less of their wealth in the form of real purchasing power $(\mathrm{M} / \mathrm{P})$. Other things unchanged, the flow of real revenue would decline at higher rates of money growth because $M / p$ declines. Even though $M$ is rising, the price level rises faster. However, other things are not unchanged. Faster money growth increases the rate of inflation and this raises the nominal interest rate $(i)$.

Faster money production exerts two opposing forces on the bank's real revenue. One force tends to reduce revenue, while the other tends to increase revenue. In general, there is a unique rate of money growth (and rate of inflation) that will maximize the flow of real revenue.

\section{A Simple Example}

Table 1 presents a hypothetical example relating different rates of inflation tor rates of monetary growth), $\pi$, to the public's demand for real purchasing power, $M / P$. In order to facilitate the calculation of the rate of inflation that maximizes the bank's revenue flow, suppose that the public knows the rate of inflation with certainty extreme rational expectations), that changes in the monetary growth rate affect only the rate of inflation and the public's desire for real purchasing power but no other real variables, that the cost of producing nominal units of money is zero iso revenue and profits are identical, that real output and population are stationary, that the real interest rate is 10 percent, and that the nominal interest rate is equal to the sum of the real interest rate and rate of inflation $(\mathbf{i}=\boldsymbol{\Gamma}+\pi)$.

The numbers in the first two columns of table 1 indicate that, as the rate of inflation rises (falls), the public's demand for real purchasing power falls (rises). The third column indicates the nominal rate of interest at the various rates of inflation. The fourth column indicates the profit stream at the different rates of inflation.

As the rate of inflation falls from very high rates, the bank's profit from inflation initially rises because people choose to hold a greater amount of real purchasing power. Reducing the rate of inflation increases total profits up to a point 1.80 real goods per unit of time in this example), after which further reductions in the rate of inflation cause profits to fall. In this example, the profit-maximizing rate of inflation (monetary growth ratel, which is the one the central bankers will choose, is 20 percent. 24

\section{THE BANK OF ENGLAND'S UNIQUE CONSTRAINTS \\ The Flow of Profits}

Among other things, the above result depends upon the particular set of operating rules the bank faces. Apart from the particular assumptions expressed above, the foregoing example does not constrain the bank in any way. If additional rules were imposed, the profit function may change. As a result, the central bankers would be confronted with different incentives, causing them to select a different monetary growth rate.

The Bank of England was founded on the condition that the stockholders grant a substantial loan to the

\footnotetext{
${ }^{24}$ Since $R=1 \times(M / P)=(r+\pi)(M / P)$, real profits are maximized when

$\frac{d P}{d \pi}=\frac{M}{P}+\frac{d(M / P)}{d \pi}(r+\pi)=0$, or

$\frac{d(M / P)}{d \pi} \frac{\pi}{M / P} \frac{(r+\pi)}{\pi}=-1$.

Hence, $n_{m}\left(\frac{r}{\pi}+1\right)=-1$,

where $n_{m}=$ the elasticity of demand for real purchasing power with respect to the rate of inflation. When $r=0$, this result reduces to $n_{m}=-1$ which is the familiar result obtained by others.

See Friedman (1953), pp. 251-62; Friedman (1971), pp. 846-56; and Baitey (1956), pp. 93-110.
} 
government at a fixed rate of interest. By 1743 , that loan amounted to almost 10 million pounds. At the point when these loans were made to the government, the interest rate charged was below the market rate. (Recall the 1694 loan at 8 percent when the market rate on long-term loans to the Crown was 14 percent.I This subsidized loan rate is a payment made by the Bank to the government for the lease rights to the production of money. The right was never granted to the Bank in perpetuity. Rather, as indicated above, the Bank's charter came up for review periodically.

The cost to the Bank of its government loan depends upon the market rate of interest. If the coupon rate is $c$ and the amount loaned is $L$, the nominal value of the lease payment per unit of time is $\{i-c) L$. The real value is the nominal amount divided by the price level $(i-c) L / P$. The higher the nominal rate of interest, $i$ relative to the coupon rate, $c$, the larger the cost of the lease to the Bank.

An additional constraint is relevant. The quantity of notes the Bank could issue was restricted by law to an amount less than or equal to the capital invested by stockholders. Since the capital represented the loan to the government, $\mathrm{M}$ must be less than or equal to $\mathrm{L}$. Given this constraint, the Bank's owners will choose $\mathrm{M}=\mathrm{L}$ because the flow of real profit is highest in this case, other things the same (see insert. Consequently, the Bank's profit is simply the coupon rate earned on the loan, $c$, times the loan which is equal to the quantity of notes issued, $M$, divided by the price level, $P$.

Table 2 illustrates the effect of this set of rules on the profit-maximizing rate of intlation for the Bank. The first three columns of table 2 simply reproduce the first three columns of table 1 . Column 4 calculates the real profits of the Bank under the new set of rules where the coupon rate, $c$, is assumed to be 10 percent. Note that profits are maximized at a zero rate of inflation rather than the 20 percent rate obtained previously. ${ }^{25}$

\footnotetext{
${ }^{25}$ This result is completely general as long as the demand for real purchasing power is inversely related to the rate of inflation. In this case,

$\frac{d R}{d \pi}=c \frac{d(M / P)}{d \pi}<0$
}

Since the derivative of the profit function with respect to the rate of inflation is negative, it does not pay the Bank to generate an inflation by continuously expanding $\mathrm{M}$ and, of course, the constraint that $M \leq L$ will eventually become binding. Given that profit maximization requires $M=L$ from expression 1 , a deflation would not benefit the Bank because it woutd require $M$ to fall below $L$. As a result, the Bank will choose a zero rate of inflation.

In addition, the Bank's owners tended to be net monetary creditors as a class and this further reduced their incentive to inflate

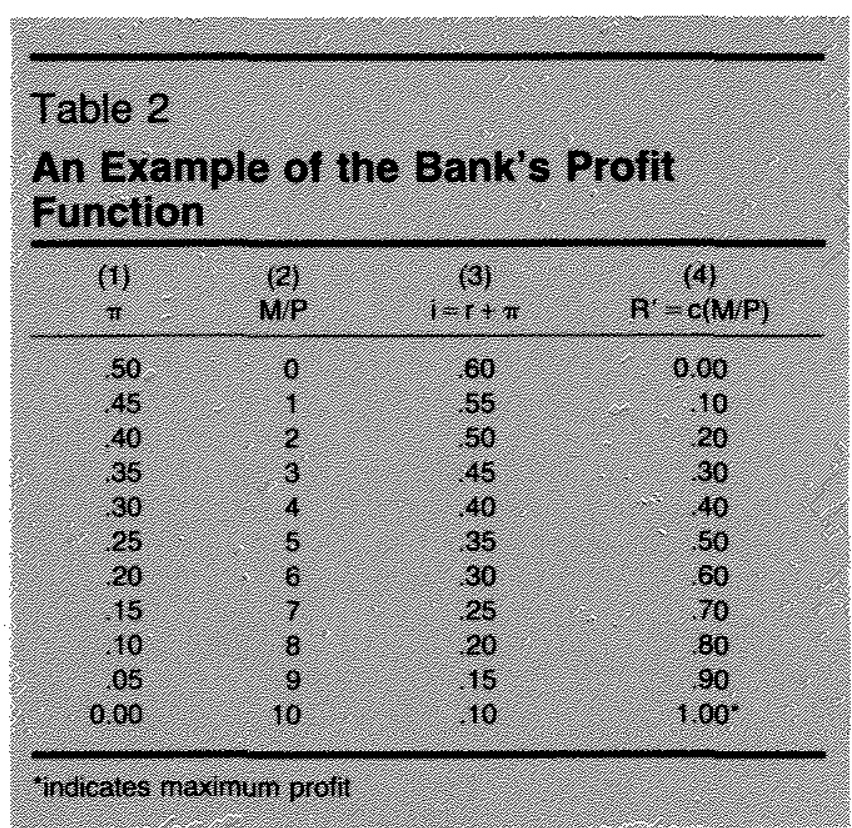

\section{The Role of Specie Payments: A Contract for Price Level Stability}

It is in the interest of Bank owners to inform the public of their intention to maintain a relatively low inflation rate. Demand for the Bank's product does not rise until the anticipated rate of inflation declines. This eventually will result from the Bank's policy of maintaining a relatively low monetary growth rate. The owners of the Bank, however, chose to hury the adjustment of expectations by "marketing" their bank notes in a particular way

In marketing its notes, the Bank guaranteed its customers a low rate of price inflation. This guarantee took the form of a contract to redeem Bank notes at a fixed price (a fixed weight of gold). The contract can be thought of as insurance against the overissue of Bank notes, because it pledged the original investment of the Bank's stockholders as surety for meeting the contract. ${ }^{26}$ If bank notes were issued in such quantity as to

There were about 1,300 original subscribers to the Bank stock. Many of them were London businessmen who were "linked sneeringly with the rather ill-famed money-lending scriveners." Others were Gentiemen and Esquires, "people who . . . live idly as 'genttemen'." See Clapham, vol. 1, pp. 273-89.

26" That double event, (1) a low identification cost to everyone about the intermediate commodity and (2) specialist-experts who provide quality assurance and information more cheaply than novices can provide for themselves, explains the use of a low identification cost commodity as a general intermediary medium of exchange-money. It permits purchase of information from lower cost sources, a cost reduction that exceeds the added cost of using an intermediary good for indirect exchange." Alchian, pp. 117-18. 


\section{The Profit Function and Sharing Arrangement}

\section{MANK ITROHITS}

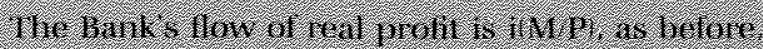

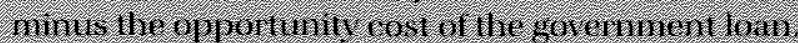
tit. elliti:

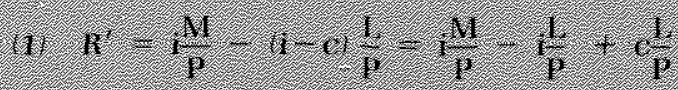

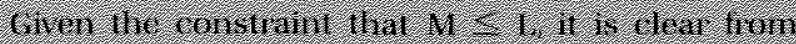

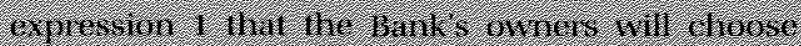

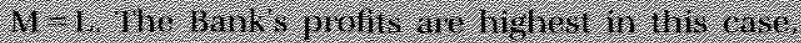

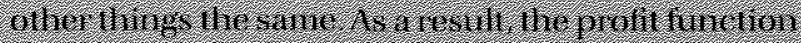
redines to

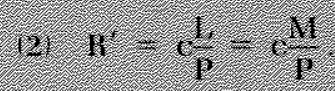

\section{SIIMTNG TIIT TAN DROM MUNIV PHonlliction}

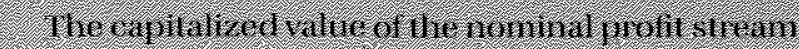
is

-3. 131 sinee the thove expression takes acrount or the

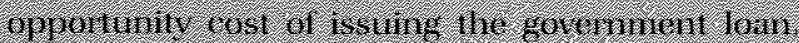
expression 3 ts the het inerease in stutktolder

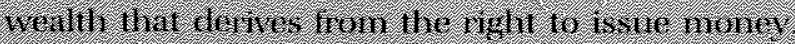

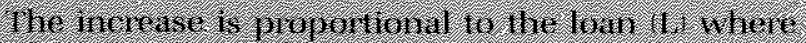

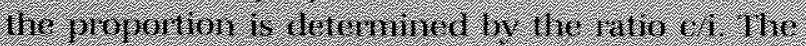

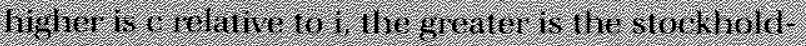

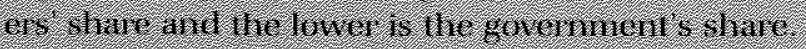

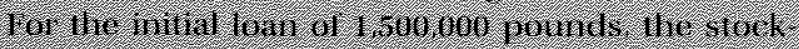

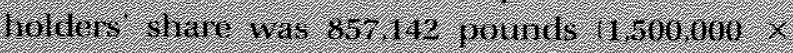
08. 14) in tertus of the prices that existert in 1694

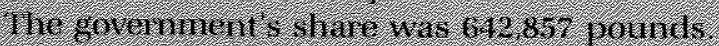

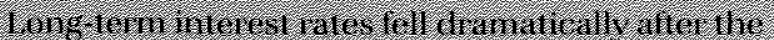

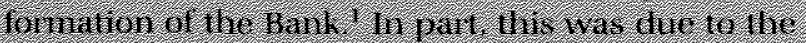
itenitual effect of Me Bank s choine of a zere rate of

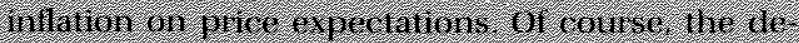
aline in lhe nominal therest rate hat the eftect of

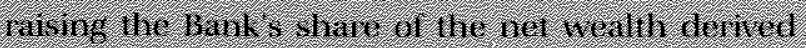

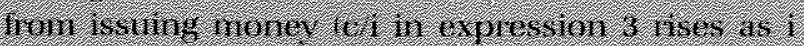

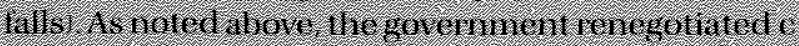

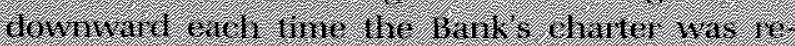

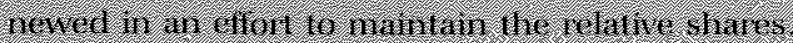

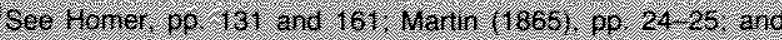

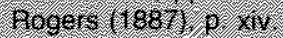

Cause their market price in terms of gold to fall below the price promised by the Bank, people would arbitrage the difference by trading gold for notes in the market at the low price and exchanging the notes for gold at the Bank for the higher price. In the process, wealth would be transfered away from stockholders to those engaging in the arbitrage. The guarantee was believable because customers knew that stockholders would lose wealth if the Bank overissued its notes relative to the supply of goods in general and gold in particular.?

\footnotetext{
${ }^{27}$ Of course. the guarantee is not perfect. New gold discoveries of improvements in mining technology would cause the price of gold and Bank notes to fall in terms of say. a standard commodity basket. However, the guarantee, while imperfect, was operational. it provided a relatively low-cost method of metering the Bank's rate of note production and policing the guarantee.
}

\section{DIFTERENT CONSTRAINTS ROR TIIE COVERNMENT}

When, for all practical purposes, the government took control of the money supply in 1793 , the constraints facing the decisionmakers changed substantialy. Recall that the government did not expropriate ownership rights in the Bank outright. Had they done so, it would have been a clear and possibly, politicaly unsavory tansfer of weath from stockholders to the govermment. The govemment, however, did the next best thing from its point of view. It expropriated the wealth of the stockholders by a more circuitous route.

When the government took over, the Bank held a loan which, while an asset to the Bank was a liability to the govemment. In terms of the example used here, an increase in the rate of inflation increases the nominal 
interest rate, $i$, and increases the Bank's opportunity cost of the government loan, $(i-c) L / P$. In effect, accelerating the rate of inflation raised the lease payment the Bank made to the govermment.

Further, during its period of cont ol, the govemment continuously violated the constraint that the quantity of notes in circulation not exceed the capital of the Bank. The government did not wish to be bound by the same rule that it believed appropriate in regulating the behavior of the Bank's stockholders.

As a result of the different constraints faced by Bank owners vs. the government, we should expect to observe rektively low rates of monetary growth and inflation during periods when the money supply is controlled by the private owners of the Bank of England and more rapid rates of monetary growth and intlation during the periods of govemment control. In addition, the demand for real purchasing power should be lowes during the period of govemment control and the price of bank stock should decline.

\section{EVIDENCE}

\section{The Behavior of English Prices}

One of the more intenesting pieces of evience concenning the efoc of different incentives is England's history of inflation dung the period of private monetary controt. England's money supply was under privale control for almost 200 vears, and the rate of inflation dumg this period was stalistically indistinsushable from zero.

From the estahlishnent of the Bank in 1694 wnt the beginning of the Napoleonic Wars in 1753 when the govemment usurped control of the money supply, the annual average rate of inflation in Fingland was of percent In 1821 , after the Napoleonic Wars, the government relurned control of the money supply to the Bank and at the Bank's insistence, established an official gold standard. Private control continued until 1913 During this period. 1822-1913, lingland's annual average rate of inflation was 42 percent which, again is statisticaly indistinguishable from zero. In contrast, by 1931, the English government had taken complete conwol of the money supply since that date, the annual average rate of inflation has been sigrificanty positive at 6.47 percent 24

\footnotetext{
28This period includes the Depression and World War II. If these years are excluded and the intlation rate is calculated over the period 1946- 82 , the mean rate of inflation is 6.87 percent ( $t-5 c o r e=9.10$ ). The t-scores for the periods 1694-1793, 1822-1913 and $1931-82$ are $, 145,489$ and 6.62 , respectively.
}

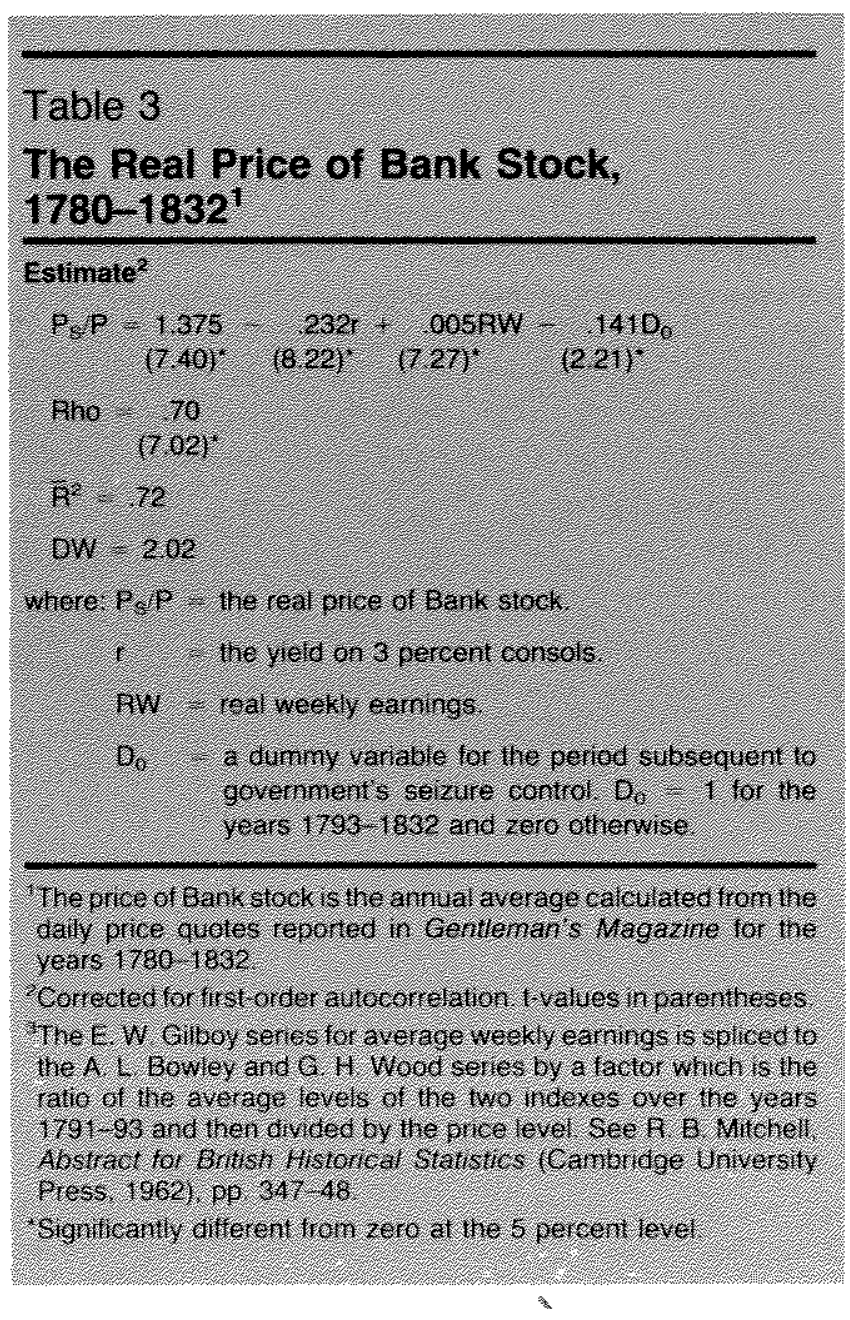

\section{The Napoleonic Wars: Additional Evidence}

The above data regarding the history of English in hation are consistent with one of the implications of the theory other aspects of the theory can be examined hy considering data from the period immediately before, during and after the Napoleonic Wars. The war is im. portant because the transfer of controt of the monev supply during the war was accomplished lwough a "gentleman's understanding" raher than an outright govermment expropriation of Bank ownership. As al result, ownership shares in the Bank continued to be exchanged by private individuals, and changes in the whe of these shares along with changes in the demand tor real purchasing power provide further avidence in regard to the theory.

\section{The Madket Price of Bank Stock}

Table 3 presents an estimate of the effect of the frovemment takeover and suspension of specie paym mens on the real price of Bank stock. The esimate 
controls for the effect of business cycles (proxied by average annual real weekly earnings of men in full-time employment and the interest rate, and includes a dummy variable for the period subsequent to the suspension. The coefficients of the business cycle proxy and the interest rate are significant and have the expected sign. The coefficient of $D_{0}$ is negative and significant. Its magnitude implies that the government takeover caused the real price of Bank stock to fall "permanently" by about 11 percent. ${ }^{29}$ In short, the govemment chose a rate of inflation that was inconsistent with maximizing the real flow of Bank profits ifrom all sources) and this was reflected in the price of Bank stock.

The price of the stock did not return to its original level when monetary control was returned to the stockholders in $1819^{30}$ This was tested by including a second dummy variable that assumes the value of 1 for the period 1793-1818 and zero otherwise, along with $\mathcal{D}_{0}$ that assumes a value of 1 for the period 1793-1832 and zero otherwise. The coefficient of the second dummy is insignificant, indicating that the variable is redundant. That is, singling out the 1793-1818 period adds nothing to the explanatory power of the equation.

In addition to this evidence, monthly data for the price of Bank and India Company stock are available for the period 1780-1801.31 There appears to be a break in the ratio of the price of Bank stock to India Company stock in 1793. Before then, the mean of the ratio was .93 with a standard deviation of .11. After 1793, the mean fell to .83 with a standard deviation of 03 . The decline in the ratio is statistically significant ${ }^{32}$ The price of Bank stock apparently declined relative to India Company stock by about 11 percent, virtually identical to the estimated decline produced by the regression in table 3 .

\section{Disgruntled Stockholders}

Understandably, the stockholders were restive during the suspension. In 1801, Alexander Allardyce,

\footnotetext{
${ }^{29}$ The estimates are adjusted for first-order autocorrelation. They were checked for second-order autocorrelation with the result that Rho 2 was insignificant.

${ }^{30}$ Durng the later part of the suspension, various moves to resume specie payments were afoot. As early as 1810 , the Bullion Report advocated a return to specie payments in 1812 . In addition, the Bank had begun a partial resumption in 1817 , and in 1819 Parliament finally committed itself to a specific date for resumption. For purposes of the following test, I terminate the period in 1818 , the year prior to Parliament's decision to retum control to the Bank.

${ }^{3}$ See Sinclair (1803), pp. 22-48.

${ }^{32}$ The t-score $=10.78$
}

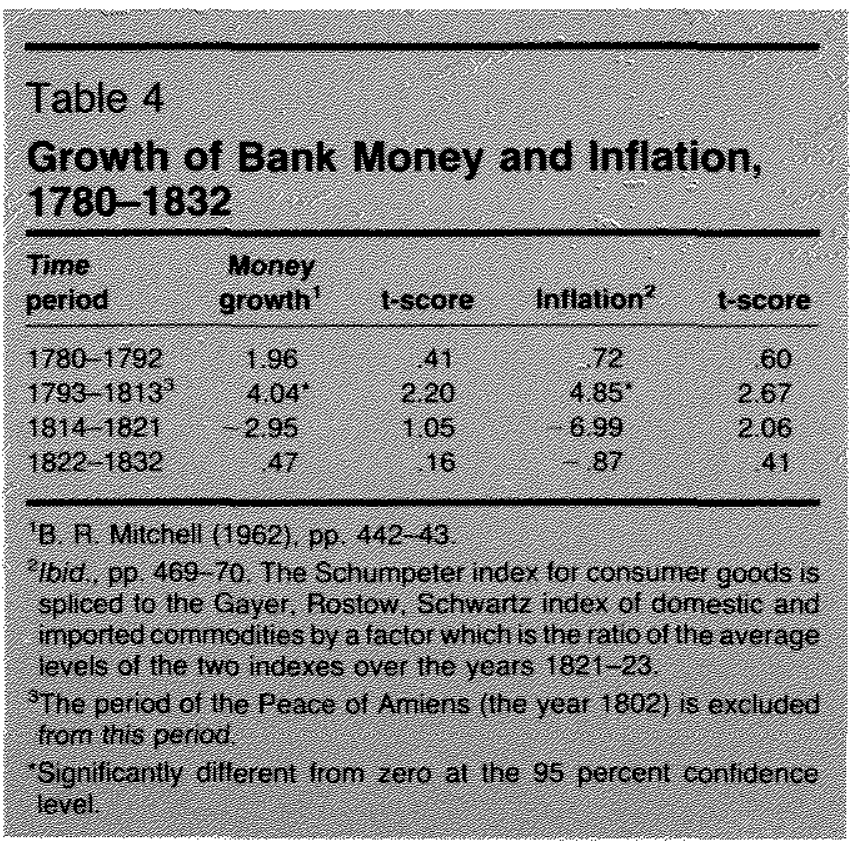

spokesman for the critics, moved that a complete accounting of the Bank's financial condition be presented to the stockholders so that the Court might "declare a dividend of the whole profits, the Charges of Management only excepted, as the Law directs."'33

Real dividend payments, inclusive of bonuses, did not increase during the suspension and the real value of Bank stock declined. These two factors along with interest-free loans made by the Bank to the government must have appeared to critics as a thinly veiled expropriation of wealth. ${ }^{34}$ They no doubt recognized the spirit of Charles II lurking in the government.

\section{Prices}

As was the case for the more extended period discussed above, the rate of inflation is indistinguishable from zero (see table 4 ) in the years immediately preceding the government takeover and those following resumption of specie payments in 1821 . In contrast, the price level rose significantly (at an average annual rate

\footnotetext{
${ }^{33}$ Clapham, vol. 2, p. 40 .

${ }^{34}$ in 1799, when the market rate of interest stood at 5.07 percent on long-term securities, the Bank made a "toan" to the government of 3 million pounds interest-free for six years. The present vatue of this gift was, roughly, 770,000 pounds. In addition, when the loan came due in March of 1806, the government asked that the loan be renewed until a point in time six months after a "Definitive Peace." The government offered to pay 3 percent interest. At the time, the long-term interest rate was considerably higher and 3 percent consols were seling at aboul a 40 percent discount.

${ }^{35}$ The years $18: 4-21$ are treated separately in table 4 . During this period, various steps were being taken to return to specie payment (see tootnote 30 ).
} 


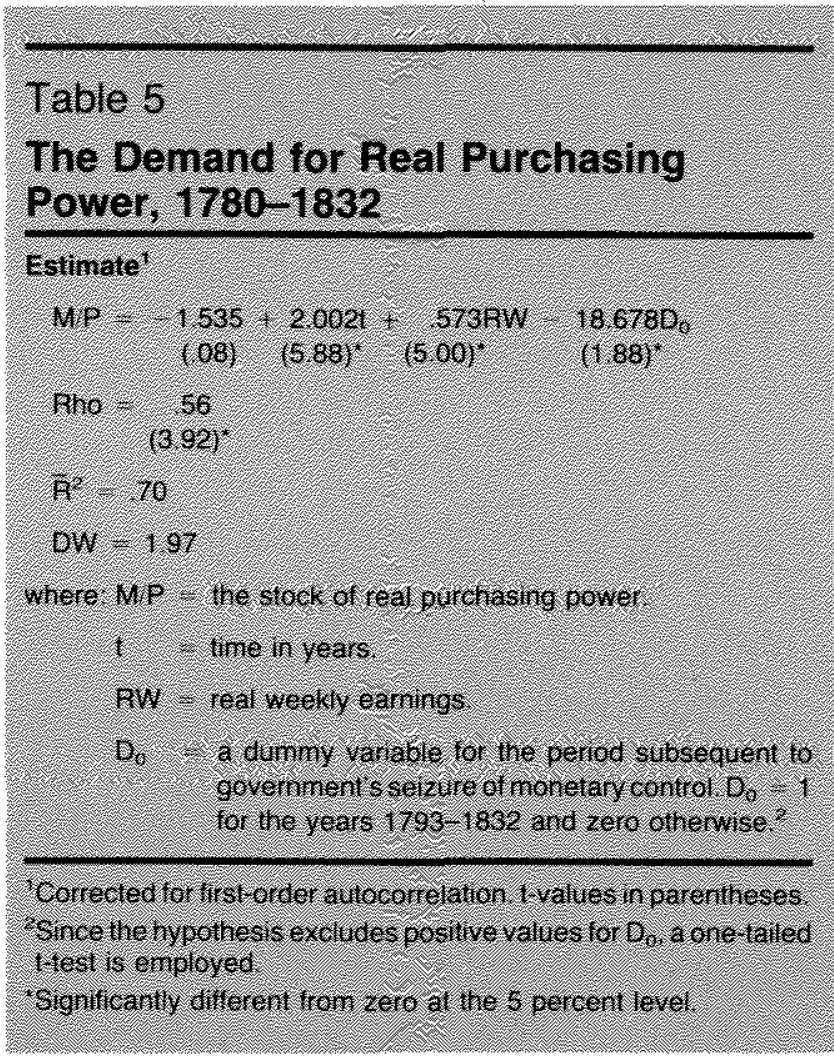

of 4.85 percentl during the years $1793-1813^{35}$ This was a result of a significant increase in the monetary growth rate. Note that the rate of inflation closely corresponds to the rate of growth in the money supply during this period ${ }^{36}$

\section{The Teal Value of Bank Money}

The theory implies that the demand for teal purchasing power will fall if the guarantee regarding the low rate of inflation is broken. ${ }^{* 6}$

\footnotetext{
${ }^{36}$ The issue of private vs. government control of the money stock might seem to be a red herring since the money supply and price leve always rise during wars. This, however, was not the case in two previous instances. During the Seven Years' War $(1755-63)$, the government did not tarmper with the Bank's control over the money supply, and the mean rates of growth in money and prices were 2.94 and 1.18 percent, respectively. Neither of these magnitudes differs significantly from zero. Similarly, during the War of Jenkin's Ear $(1739-43)$, the mean rates of growth in money and prices were -1.62 and .66 percent, respectively. Again, neither of these differs significartly from zero.

${ }^{37}$ Exactly wher the public became aware of a break in the trust is problematical. They certainly were aware of it by 1797 when the government ordered the Bank to suspend specie payments. The data, however, suggest an earlier date. Prices began rising fapidly in 1790 and, shorty afterwards, the public began arbitraging the difference between the price of gold in terms of notes at the Bank and its price in the foreign market. The Bank's bullion account began to decine in 1791, then fell substantially in 1792. The following
}

Table 5 presents a regression that estimates the effect of the government's seizure of control over the money supply on the demand for real purchasing power by controlling for the effect of business cycles population and the altemative cost of holding money Annual population data are not avalable back to 1780 so time is used as a rough proxy to control for popula. tion growth. The interest rate on 3 percent consols was included as a measure of the altemative cost of holding wealth in the form of money. In addition, a dummy variable is included to test for a shift in the relationshir in the period subsequent to the government takeover

The coefficients of the proxies for the business cycle and population are significant and have the expected signs. The interest rate proved insignificant and was excluded from the estimate. The coefficient of $D_{0}$ is negative and significant. Its magnitude implies that the demand for real purchasing power fell by about 12 percent when the government seized control of the Bank. ${ }^{3 r}$

\section{CONCLUSION}

The above analysis suggests that decisions regarding the control of money depend more on the incentives individuals face in making choices than on the particular individuals who make the choice. Various methods of organizing monetary control produce distinct policy outcomes insofa as they confront policymakers with different incentives. Since it is unclear, for example, that the incentives confronted by the policymaker would be much different if monetary control were placed in the hands of Congress or the Treasury instead of the Boand of Governors, it is unclear that the adoption of either of these altematives would cause a noticeable change in policy. Additional research along these lines may prove helpful in suggesting a system of incentives that will induce the present-day equivalents of the Court of Directors to assign the desired weights whatever they happen to bel to present and future consequences in reaching decisions regarding monetary control.

assumes the public became aware of the break in 1793 when the war with France began.

${ }^{38}$ As was the case with the price of Bank stock, the dernand tor real purchasing power dio not return to its original level when the government retumed monetary control to the Bank and the guarantee was reinstated. This was tested by the same procedure as that employed in the case of the price of Bank stock. The resulis were the same. The coefficient of the second dummy was insignificant, indicating that it is redundant 


\section{REFERENCES}

Alchian, Armen A. "Some Economics of Property Rights," Economic Forces at Work (Lberty Press, 1977).

Andreades, A. History of the Bank of England (P. S. King and Son, 1924).

Bailey, Martin L. "The Wefare Cost of Inflationary Finance," The Joumal of Political Economy (April 1956), pp. 93-110.

Batbach, Anatol B. "How Controllable is Money Growth?" this Review (April 1981), pp. 3-12

Bisschop, W. R. The Rise of the London Money Market: 1640-1826 (Buft Frankin, 1967 ).

Cannan, Edwin. The Paper Pound of 1797-182) (P. S. King and Son, 1919)

Clapham, Sir John. The Bank of England a History, vols. 1 and 2 (Cambridge University Press, 1958).

Friedman, Miton. "Discussion of the Intlationary Gap," Essays in Positive Economics (University of Chicago Press, 1953).
"Government Revenue from Intlation," Journal of Politi. cal Economy (July/August 1971). pp. 846-56.

Homer, Sitney. A History of Interest Rates (Rutgers University Press, 1977).

Johannes, James M. and Robert H. Rasche. "Predicting the Money Multiplier," Journal of Monetary Economics (July 1979), pp. 30125.

Kemmerer, Edwin W. Gold and the Gold Standard (McGraw-Hill, 1944).

Macleod, M. A. The Theory of Credit, 2nd ed. Longmans, Green and Co., 1897), vol, 2, patt 2.

Martin, Frederick. Stories of Banks and Bankers (Macmillan and Co., 1865).

Rogers, Thorold. The First Nine Years of the Bank of England (Clarendon Press, 1887 ).

Sinclait, Sir John. The History of Public Revenue of the British Empire (A. M. Kelly: New York, 1803).

Viner, Jacob. Studies in the Theory of International Trade (Harper and Brothers, 1937 ). 